George, A. J., Copeland, J. R. M. \& Wilson, K. C. M. (1980) Serum prolactin and the postnatal blues. British Journal of Pharmacology, 70, 101-102.

- \& WILSON, K. C. M. (1981) Monoamine oxidase activity and the puerperal blues syndrome. Journal of Psychosomatic Research, 25, 409-413.

_ (1982) Maternal B-endorphin/B-lipotrophin correlates with prolactin in the first postpartum week. Journal of Clinical Pharmocology, 14, 146-147.

\section{EXAMINING CHILDREN WHO ARE WARDS OF COURT}

DeAR Sir,

A physician referred an anorexic girl to me for treatment. I assessed her, confirmed the diagnosis and transferred her for treatment under my care in the children's ward. This necessary action almost caused the County Council to be in contempt of Court because this girl is a Ward of Court. About the same time, mention was made at a clinic meeting that a disturbed child could not be seen at the clinic because he was a Ward of Court and the Court would not allow such an examination.

These disturbing events made me seek advice from the County Solicitor and the Medical Protection Society. It seems that divorcing parents, who were contesting guardianship and access, tended to use psychiatric reports as ammunition against each other. The Court, in order to protect children from such unnecessary investigation ruled that "it is improper for a Ward of Court to be psychiatrically examined without the consent of the Court or of the Official Solicitor or the minor's guardian ad litem". Fortunately, it is subsequently clarified that "this does not interfere with the discretion of a parent having de facto custody to take a sick child to a doctor".

It therefore seems that the consent of the Court needs to be obtained before a child, who is a Ward of Court, can be seen by a pscyhiatrist. I understand this is not so if a child needs to be seen by any other specialist. Readers of this journal will be well aware of the difficulties that have to be overcome by parents in order to seek the advice of a child psychiatrist. It seems to me that such discrimination could be restricting the number of children who could benefit from psychiatric treatment and could therefore place at a disadvantage the very children that it sets out to protect. I would be very interested to hear if colleagues have had similar experiences, although of course it is very difficult for psychiatrists to be aware of how many children who need to be seen are not seen.

Child and Family Guidance Clinic,

Jason Maratos

56 Amersham Hill, High Wycombe HP13 6PQ

\section{CORRECTION}

DEAR SIR,

'Schizophrenic Patients Discharged from Hospital-A Follow-up Study'. Johnstone et al, Journal, December 1984, 586-590.

I regret that when this paper was published the majority of the corrections that we made at the proof stage were not incorporated. Most of these were relatively trivial grammatical and spelling errors, but I am afraid that there is one error which is seriously misleading and which I would like to bring to the attention of readers of the Journal: Page 589; column 1, paragraph 2-the first sentence reads: "The findings indicate that recovery from schizophrenia does not take place ..."

This is wrong-'does not' should have been replaced with 'may'. Perceptive readers I am sure will have noticed that there must be an error at this point in the article but I would like to be sure that there is no confusion over this issue and to make it clear that what we wanted to say is: "The findings indicate that recovery from schizophrenia may take place even in patients fulfilling the St. Louis criteria for that diagnosis".

Clinical Research Centre,

Eve C. Johnstone 